\title{
ESTIMATES OF HEAT AND PYROCLAST DISCHARGE BY VOLCANIC ERUPTIONS BASED UPON THE ERUPTION CLOUD AND STEADY PLUME OBSERVATIONS
}

\author{
S. A. FEDOTOV \\ Institute of Volcanology, Petropavlovsk-Kamchatsky, 683006 USSR. \\ (Received December 20, 1984)
}

\section{ABSTRACT}

Fedotov, S. A., 1985. Estimates of heat and pyroclast discharge by volcanic eruptions based upon the eruption cloud and steady plume observations, Journal of Geodynamics, 3: 275-302.

Fumarolic steam plumes and eruption clouds rise like convective turbulent columns into the atmosphere. Formulae are presented here for estimating the heat power of plumes, the production rate of juvenile pyroclasts ejected during eruptions and the heat output of fumaroles. Their accuracy is tested using the well-studied examples of eruptions of Kamchatkan volcanoes.

The Briggs (1969) formula may be used in observing the ascending part of a plume in crosswinds. The best results have been obtained using the CONCAWE formula which permits estimation of the heat power in crosswinds based on the axis height of a horizontal part of a maintained plume. Three connected equations have been suggested for a stable atmosphere and calm weather conditions. The first one, which is applicable for heights ranging from $100 \mathrm{~m}$ to $1 \mathrm{~km}$, is the formula proposed by Morton et al. (1956). This equation changes for higher layers of the troposphere $(1-10 \mathrm{~km})$ and stratosphere $(10-55 \mathrm{~km})$.

A classification scale was constructed allowing us to compare volcanic eruptions and fumarolic activity in terms of the intensity of their plumes.

The described method is useful for volcano surveillance; it helps in the study of the energetics and mechanics of volcanic and magmatic processes.

\section{INTRODUCTION. SELECTED FORMULAE}

The generation of gas-ash or gas-pyroclastic plumes and fumarolic or explosive eruption clouds, their rise, dispersal of pyroclasts and their influence on the atmosphere-this group of questions represents a part of the theory on volcanic eruptions.

Fumarolic and gas-pyroclastic plumes, eruption columns and clouds are natural phenomena differing by many orders of magnitude in power. Like volcanic eruptions, they also differ in character. However, the physics of 
their ascent and mixing with ambient air is similar. In these cases, the momentum of gas and pyroclasts ejected from vents is decreased at some height owing to air resistance and then an expanding hot cloud floats up through the atmosphere, forming a convective column blown by the wind.

The study of similar physical processes and phenomena in the atmosphere is a branch of aerology and meteorology. Their theoretical investigation is carried out using the methods of fluid dynamics.

In addition to their scientific interest, these studies have great practial value for investigations of the problems of air pollution by industrial smokes, dispersal of radioactive precipitates of nuclear explosions, as well as of the aerodynamics of clouds and propagation of major fires. These problems have been considered by many authors, e.g. Briggs $(1969 ; 1971)$; Wark and Warner (1976); Knox and Short (1964); Gostintsev et al. (1980). The problem related to volcanic gas and fine-sized pyroclast injection into the stratosphere, which may occur during the largest volcanic explosions, is important for climatology and a number of applied sciences.

Quantitative relations between the heat power of a hot gas source, the atmospheric conditions and the convective column heights have been obtained by theoretical and empirical means through studying the clouds from large explosions and the dispersion of smoke above industrial stacks and electric power stations. Volcanologists have used these relations for estimating the power of eruptions and fumaroles (e.g., Settle, 1978; Wilson et al., 1978; Kienle and Shaw, 1979; Kagiyama, 1981; Kagiyama and Hagiwara, 1981; Fedotov et al., 1981; 1982; Fedotov, 1982; Sparks and Wilson, 1982).

A variety of theoretical and empirical formulae are available for calculating the ascent of convective plumes and hot gas clouds produced by large explosions and industrial stacks for continuous and instantaneous sources in different atmospheric conditions. We shall now list several formulae which may be used widely in volcanology.

A convective column ascends vertically upwards in a slow crosswind and with calm weather conditions, as well as when the ascent velocity of eruption cloud greatly exceeds the crosswind velocity. A theoretial solution for this case was given by Morton et al. (1956). They investigated the turbulent gravitational convection of plumes from continuous and instantaneous sources. If the atmosphere is stable, the maximum height $\Delta \mathrm{h}_{\mathrm{T}}$ of the convective cloud of a continuous source is expressed as:

$\Delta \mathrm{h}_{\mathrm{T}}, \mathrm{m}=31 \cdot\left(1-\frac{\Gamma}{\Gamma_{0}}\right)^{-\frac{3}{8}} \cdot(\mathrm{Q}, \mathrm{kW})^{\frac{1}{4}}$

where $\mathrm{Q}$ is the heat power of source in kilowatts, $\Gamma=\frac{\Delta \mathrm{T}}{\Delta \mathrm{Z}}$ is the mean 
vertical temperature gradient of ambient air and $\Gamma_{0}=-9.8^{\circ} \mathrm{C} / \mathrm{km}$ is the adiabatic gradient of the air (Morton et al., 1956). A scheme of the cloud is shown in Fig. 1. As is seen from (1) the convective cloud height depends strongly on the temperature gradient and it must be lower when warm air is above. For a standard temperature gradient of ambient air, $\Gamma=$ $-6.5^{\circ} \mathrm{C} / \mathrm{km}$, the formula (1) becomes

$\Delta \mathrm{h}_{\mathrm{T}}, \mathrm{m}=46 \cdot(\mathrm{Q}, \mathrm{kW})^{\frac{1}{4}}$

or

$\mathrm{Q}, \mathrm{kW}=\left(\frac{\Delta \mathrm{h}_{\mathrm{T}}, \mathrm{m}}{46}\right)^{4}$.

For instantaneous source (explosion) in the same atmospheric conditions as for (1), i.e. with a slow crosswind and stable atmospheric conditions, the similar Morton et al. (1956) formula is expressed as

$\Delta \mathrm{h}_{\mathrm{T}}, \mathrm{m}=1.24 \cdot\left(1-\frac{\Gamma}{\Gamma_{0}}\right)^{-\frac{3}{8}} \cdot(\mathrm{Q}, \mathrm{J})^{\frac{1}{4}}$
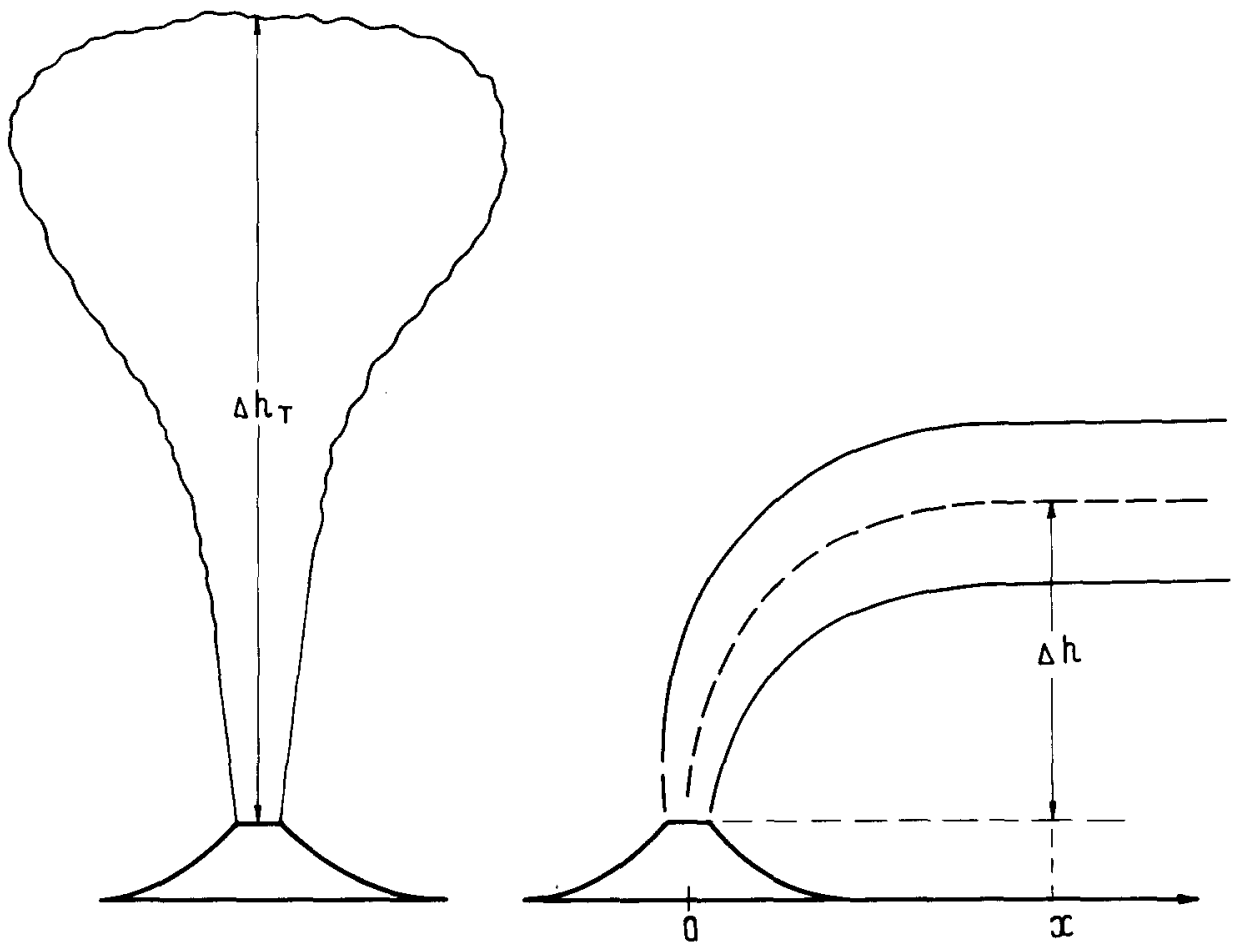

Fig. 1. Schematic view of maintained eruption plume in calm weather and with crosswind. 
where $Q$ is the heat energy of source in J. For a standard stable atmosphere, $\Gamma=-6.5^{\circ} \mathrm{C} / \mathrm{km}$, this formula is simplified

$\Delta \mathrm{h}_{\mathrm{T}}, \mathrm{m}=1.87 \cdot(\mathrm{Q}, \mathrm{J})^{\frac{1}{4}}$

In crosswinds a rising convective gas plume forms a tail at its ceiling height. If the atmosphere is stable, the tail stretches horizontally at the height $\Delta \mathrm{h}$ or fluctuates near this height. More rapid and strong mixing of the plume with ambient air occurs in a crosswind, but this is not taken into consideration in formulae (1-4).

A number of other formulae applicable for calculations in crosswinds were given by Briggs $(1969 ; 1971)$ who has made a complete review of the rise of industrial smoke and the air pollution. It is noted that the scatter in estimates obtained using different formulae reaches an order in magnitude.

It is shown how strongly the height of the smoke plume and its dispersion depend on the atmospheric conditions. Changes in smoke height observed at a big coal power station in Tennessee during a day were given as an example. In a stable atmosphere, the height changed from 300 to $1000 \mathrm{~m}$. It is noted that no single formula can fit for calculations of the height of plumes of any heat power under any atmospheric conditions and, therefore, it is necessary to select the proper one.

Briggs recommends the following formula

$$
\Delta \mathrm{h}=1.6 \cdot \mathrm{F}^{\frac{1}{3}} \cdot \mathrm{u}^{-1} \cdot \mathrm{x}^{\frac{2}{3}}
$$

where $\Delta \mathrm{h}$ is the height of the median line of the smoke plume above the top of the stack (above the crater) at distance $x$ from the crater, see Fig. 1; $u$ is the crosswind velocity above the stack (above the crater); $h$ and $x$ are expressed in $\mathrm{m}, \mathrm{u}$ in $\mathrm{m} / \mathrm{sec}, \mathrm{F}=3.8 \cdot 10^{-5} \cdot \mathrm{Q} \mathrm{cal} / \mathrm{sec}$, where $\mathrm{Q}$ is the heat power of the gas plume. Formula (5) may be rewritten as

$\mathrm{Q}, \mathrm{W}=2.7 \cdot 10^{4} \cdot \Delta \mathrm{h}^{3} \cdot \mathrm{u}^{3} \cdot \mathrm{x}^{-2}$

or

$\mathrm{Q} \mathrm{cal} / \mathrm{sec}=6.43 \cdot 10^{3} \cdot \Delta \mathrm{h}^{3} \cdot \mathrm{u}^{3} \cdot \mathrm{x}^{-2}$

Equations (5-7) should give the best results at small absolute heights when $\mathrm{Q}=20-120 \mathrm{Mw}$. It is notable that such measurements may be carried out in the zone of rapid initial plume rise where influence of meteorological conditions is negligible.

After a rapid rise, the smoke plume generally stretches down wind, remaining at a certain height. In this case, in a stable atmosphere the height 
of the median line of the horizontal portion of the plume $\Delta \mathrm{h}$ is expressed by the formula

$\Delta \mathrm{h}, \mathrm{m}=0,0975 \cdot\left(\mathrm{Q} \cdot \mathrm{u}^{-1} \cdot \mathrm{S}^{-1}\right)^{\frac{1}{3}}$

where $\mathrm{Q}, \mathrm{cal} / \mathrm{sec}$ is the heat power of the source; $\mathrm{u}, \mathrm{m} / \mathrm{sec}$ is the crosswind velocity; $\mathrm{S}=\frac{\mathrm{g}}{\mathrm{T}^{\circ} \mathrm{K}} \cdot \frac{\Delta \Theta}{\Delta \mathrm{Z}}$, where $\mathrm{g}$ is the gravitational acceleration and $\mathrm{T}^{\circ} \mathrm{K}$ is the absolute temperature of the ambient air; $\frac{\Delta \Theta}{\Delta \mathrm{Z}}=-\frac{9.8^{\circ} \mathrm{C}}{1000 \mathrm{~m}}+$ $\frac{\Delta \mathrm{T}}{\Delta \mathrm{Z}}$ is the potential temperature gradient of ambient air, where $\mathrm{T}$ is the ambient air temperature and $\mathrm{z}$ is the height (e.g., Briggs, 1969; 1971). The coefficient $\mathrm{S}$ in formula (8) is assumed to be constant. In practice, its average value is used.

When the top boundary of the horizontal portion of the plume is seen better the similar formula may be used

$\Delta \mathrm{h}_{\mathrm{T}}, \mathrm{m}=0.135 \cdot\left(\mathrm{Q} \cdot \mathrm{u}^{-1} \cdot \mathrm{S}^{-1}\right)^{\frac{1}{3}}$

The formula for estimating the height of the median line of the horizontal portion of the plume, $\Delta \mathrm{h}, \mathrm{m}$, proposed by the International Working Group on Conservation of Clean Air and Water, Western Europe (CONCAWE) is more simple

$\Delta \mathrm{h}, \mathrm{m}=2.71 \cdot \mathrm{Q}^{\frac{1}{2}} \cdot \mathrm{u}^{-\frac{3}{4}}$

or

$\mathrm{Q}, \mathrm{kW}=0.136 \cdot \Delta \mathrm{h}^{2} \cdot \mathrm{u}^{1.5}$

where $\mathrm{Q}, \mathrm{kW}$, is the heat power of the plume rising above the stack; and $\mathrm{u}$, $\mathrm{m} / \mathrm{sec}$, is the crosswind velocity at stack-top level (Briggs, 1969; Wark and Warner, 1976).

When similar formulae are used in volcanology, the average horizontal crosswind velocity at heights from the vent to the top of plume is employed (e.g., Settle, 1978). (Our experience has demonstrated that it is better to take a velocity at the height of the horizontal part of the plume). Formula (10) is in good agreement with observations of industrial stack plumes.

All the above-mentioned formulae were tested by analysing the industrial stack smoke from hundreds of big electric power stations and plants; the heat power of their plumes reached $120 \mathrm{Mw}\left(120 \cdot 10^{3} \mathrm{kw}\right)$. The heat power of volcanic smoke in the period between eruptions and the heat discharged by fumaroles in most cases do not exceed $250 \mathrm{Mw}$ (Kagiyama, 1981). The 
formulae given above are probably valid for estimations of the energy of volcanic activity of such a power.

The heat power of volcanic eruptions is several orders of magnitude greater, $10^{12}-3 \cdot 10^{15} \mathrm{cal} / \mathrm{sec}$ or $4 \cdot 10^{6}-10^{10} \mathrm{Mw}$ (e.g., Settle, 1978). Extrapolation of formulae (1-10) to the field of such large powers has yet to be proved.

The papers mentioned in this section do not show if it is possible to determine the eruption power in strong crosswinds using formulae (1-10).

In order to test the possibility of extrapolation, as well as the accuracy of formulae for eruption plumes in crosswinds we shall use the data on the most recent large eruptions of Tolbachik (1975-1976) and Alaid (1981) volcanoes.

ESTIMATES OF FORMULA ACCURACY ACCORDING TO DATA ON THE GREAT TOLBACHIK FISSURE ERUPTION (1975-1976) AND THE ALAID ERUPTION (1981)

\section{The Northern Breakthrough of the Tolbachik Eruption}

The great Tolbachik fissure eruption occurred within the Southern zone of cinder cones of the Plosky Tolbachik volcano in Kamchatka from 6 July, 1975 till 10 December, 1976. This was the largest basalt eruption in historical time in the Kurile-Kamchatka volcanic belt. The volume of its erupted products exceeds $2 \mathrm{~km}^{3}$. More than a hundred papers and several books have been devoted to investigations of different aspects of this eruption. Descriptions of the course of the eruption and its main characteristics are given in a number of papers (e.g., Fedotov et al., 1977; Fedotov et al., 1983; Fedotov et al., 1980; Fedotov, 1982) and in a large summarizing monograph The Great Tolbachik Fissure Eruption,....(1984).

During the first 72 days the eruption took place at the Northern Breakthrough. As a result of its activity three large basaltic cinder cones formed. Their height was up to $300 \mathrm{~m}$ and the total volume was about $0.3 \mathrm{~km}^{3}$. The volume of lava effused was $0.24 \mathrm{~km}^{3}$. The volume of pyroclastic material deposited outside the cones was $0.68 \mathrm{~km}^{3}$. The ratio of the volume of pyroclastic material to the whole volume of erupted rocks was equal to $\mathrm{E}=80 \%$. Powerful gas-pyroclastic jets were fountaining from the craters. The exit velocity of these jets was about $200 \mathrm{~m} / \mathrm{sec}$ on the average and the diameter of their lower compact portion did not exceed $50-60 \mathrm{~m}$. The incandescent jet of pyroclasts resembled the flame of a candle $0.5-1.0 \mathrm{~km}$ and occasionally $2.5 \mathrm{~km}$ high. Volcanic bombs rose to heights of $0.3-0.5 \mathrm{~km}$ during the first days of the eruption, then to $2 \mathrm{~km}$, at times to $4 \mathrm{~km}$ and more. Almost all the erupted material was juvenile basalt. 
The data mentioned above permit us to make a rough upper estimate of the volatile content in the basaltic magma of the Northern Breakthrough. In the case when all the energy of gas expansion during a volcanic explosion turns into kinetic, the gas represents steam, the eruption is explosive and all the pyroclastic material is juvenile, the following equation is acceptable:

$\mathrm{U}^{2}, \mathrm{~m} / \mathrm{sec}=8 \cdot 10^{3} \cdot \mathrm{c} \cdot\left(2 \mathrm{c}^{0,3}-1\right)$

where $\mathrm{U}$ is the exit velocity of pyroclast ejection, $\mathrm{c}$ is the water content in the magma in weight percent (Markhinin, 1958; 1980). If $U=200 \mathrm{~m} / \mathrm{sec}$, the water content constitutes $3 \%$ or less.

Equation (11) is approximate. New equations were derived by Wilson (1980) for the plinian, strombolian and vulcanian activities. It follows from these that the water content in magma constitutes $1.5 \%$ if the velocity of a basaltic pyroclast plume is $220 \mathrm{~m} / \mathrm{sec}$.

The impressive aspect and the activity of the eruption column at the Northern Breakthrough have demonstrated many of those features that were described by the theoretical model (e.g., Walker et al., 1971; Wilson, 1976; Wilson et al., 1978; Wilson and Head, 1981).

Incandescent gas-pyroclastic "candles" $0.5-2.5 \mathrm{~km}$ high formed the base of the eruption column (The Great Tolbachik Fissure Eruption, 1984). The gas-pyroclastic plume was turbulent, surrounded by toroidal whirls and expanded upwards, forming a narrow cone with an angle of about $15^{\circ}$. The top of the "candle" was hidden in black curling clouds of cooled ash that enveloped the plume in a few seconds after its ejection from the crater. The curling eruption cloud expanded and rose rapidly to a height of $12 \mathrm{~km}$ above the crater in calm weather and to $5 \mathrm{~km}$ in strong crosswinds. Pyroclastic products fell down from the eruption column. Incandescent bombs and large lumps of cinder reached the earth's surface. They fell mainly on the slopes of the cones. Outside the cones, at a distance of $2.7 \mathrm{~km}$ from the crater of the second eruption cone, the author observed a fall of cinders, that were still red inside and which were $5 \mathrm{~cm}$ in size and more, only with a strong crosswind. A rain of lapilli recommenced at a distance of $3.5 .4 \mathrm{~km}$ from the crater of cone I several minutes after the intensifiction of explosive activity. Within a few minutes lappili ejected in the eruption column to a height of several kilometres were drifted by the wind and fell to the ground in a cold or barely warm state. These observations show that cooling velocities of pyroclasts of different sizes in the eruption cloud were close to those which were expected according to calculations (Wilson et al., 1978). Heat was transferred rapidly from volcanic dust, sand, gravel and lapilli to the eruption cloud of the Northern Breakthrough.

Mapping and investigation of pyroclastic deposits at the Northern Breakthrough were carried out (Budnikov et al., 1983; 1979; Maleyev et al., 
1979). The near-crater part of the new cinder cones is composed mainly of coarse-sized pyroclasts, but at the foot of these cones $0.5-2 \mathrm{~cm}$-sized pyroclasts predominate. Two-mm-sized gravel and $0.5-2 \mathrm{~mm}$-sized sand fell at a distance of up to 15 and $20 \mathrm{~km}$ from the cones, respectively. The density of fractions changed in the following way: $0.5 \mathrm{~g} / \mathrm{cm}^{3}$ for $1-2 \mathrm{~cm}$-sized lapilli, $0.6-0.7 \mathrm{~g} / \mathrm{cm}^{3}$ for $1.25-10 \mathrm{~mm}$-sized gravel and $0.9-1.2 \mathrm{~g} / \mathrm{cm}^{3}$ for different fractions of volcanic sand. The average weight of cinder per unit of volume was $0.8 \mathrm{~g} / \mathrm{cm}^{3}$. The total volume of pyroclastics deposited outside the cones was two times greater than the volume of cones and was estimated as $0.68 \mathrm{~km}^{3}$ of which $20 \%$ was accounted for by fractions more than $2 \mathrm{~mm}$ in size with a density of $0.8 \mathrm{~g} / \mathrm{cm}^{3}$ and $80 \%$ represented sand and dust less than $2 \mathrm{~mm}$ in size with a density of $1.1 \mathrm{~g} / \mathrm{cm}^{3}$.

Ash of the Northern Breakthrough was represented mainly by juvenile dark basaltic glass (Budnikov et al., 1983; Budnikov et al., 1979). The temperature of the fluid lavas was $1050-1070^{\circ} \mathrm{C}$ and more. The glass ejected from the crater must contain at the exit considerable amounts of hidden heat of melting. Assume that the exit temperature of the Northern

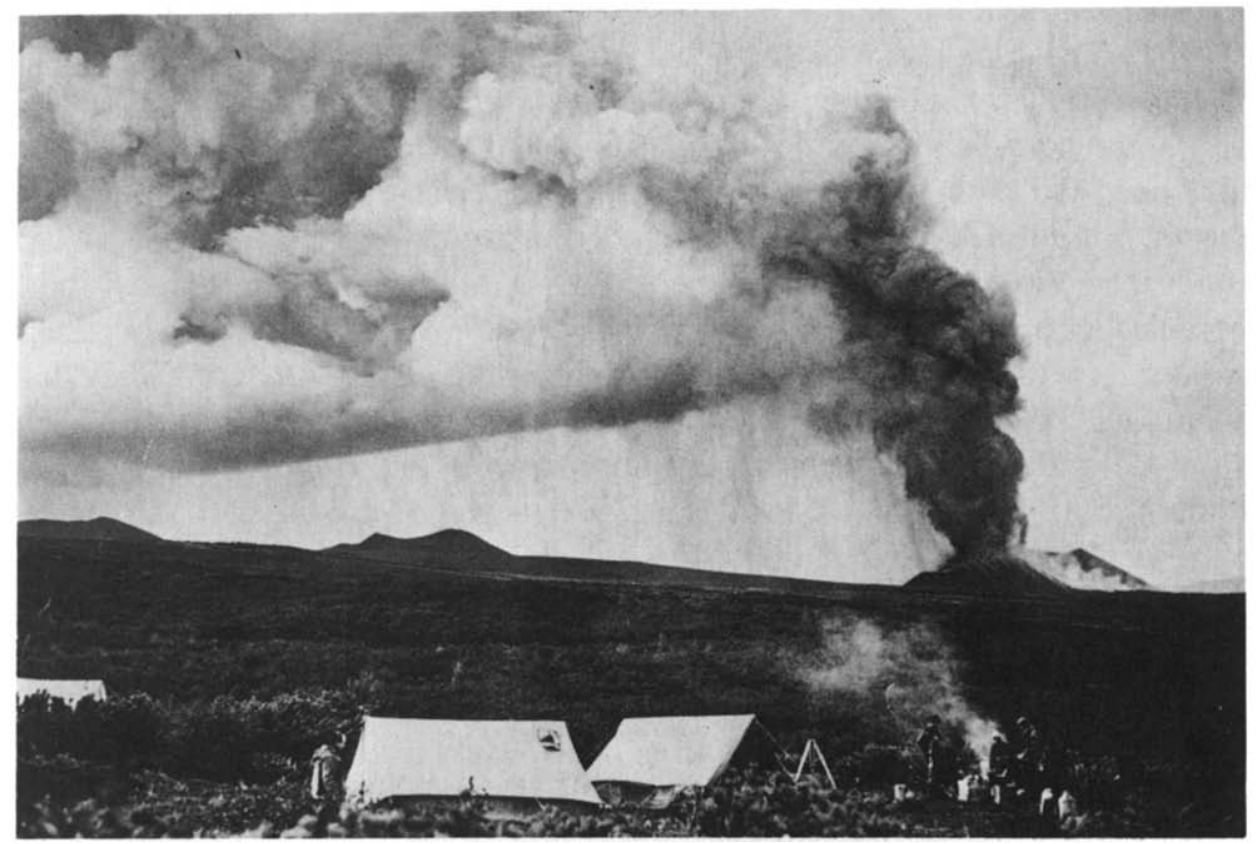

Fig. 2. Activity of cone II of the Tolbachik Northern Breakthrough on 4 September 1975. Dense highspeed jet rises from the crater to a height of $2 \mathrm{~km}$ then it is bent over by the wind and turned into a wide plume. Crosswind velocity at a "ceiling" height of the plume is about $26 \mathrm{~m} / \mathrm{sec}$. Distance is $8 \mathrm{~km}$. Photo by S. A. Fedotov. 
Breakthrough pyroclastics was $1050^{\circ} \mathrm{C}$, its heat capacity was $0.25 \mathrm{cal} / \mathrm{g} \cdot{ }^{\circ} \mathrm{C}$ and it contained half the heat of melting $(50 \mathrm{cal} / \mathrm{g})$

We neglect two contrarily-acting factors, namely heat of a few weight percent of magmatic gases which increase the energy of the eruption cloud and heat of coarse pyroclasts fallen outside the cones.

During the 72-day activity of the Northern Breakthrough, approximately $0.68 \mathrm{~km}^{3}$ of fine-sized pyroclasts were evenly ejected. Under such conditions, the heat power of the Northern Breakthrough eruption column was equal to $3.52 \cdot 10^{10} \mathrm{cal} / \mathrm{sec}=1.47 \cdot 10^{5} \mathrm{Mw}=147 \cdot 10^{6} \mathrm{kw}$.

Exact information on the eruption cloud was obtained on 4 September, 1975, by aerial survey (Abramovsky et al., 1979). The character of the eruption that day is shown in Fig. 2. The maximum width of the eruption plume at a distance of $100 \mathrm{~km}$ from the crater was $20 \mathrm{~km}$. Its bottom boundary was at a height of about $1 \mathrm{~km}$ and the top boundary was at a height of $6 \mathrm{~km}$. The axis of plume was at a height of $4 \mathrm{~km}$ and is clearly seen in graphs showing the change of $\mathrm{SO}_{2}$ concentration in the vertical direction (Fig. 3). During the observations the average crosswind velocity at heights of $1-4 \mathrm{~km}$ and $5-7 \mathrm{~km}$ was equal to 60 and $130 \mathrm{~km} / \mathrm{hr}$, respectively. The absolute height of the crater vent was approximately $1 \mathrm{~km}$.

If we take $\Delta \mathrm{h}=3000 \mathrm{~m}$ and $\mathrm{u}=(60+130) / 2 \mathrm{~km} / \mathrm{hr}$ and use the CONCAWE formula (10) in order to estimate the heat power of the eruption plume, $\mathrm{Q}$, then we obtain $\mathrm{Q}=166 \cdot 10^{6} \mathrm{kw}$ which is close to the expected value of $147 \cdot 10^{6} \mathrm{kw}$. If we take the crosswind velocity at the height of the crater, $\mathrm{u}=16.7 \mathrm{~m} / \mathrm{sec}$, then $\mathrm{Q}=83 \cdot 10^{6} \mathrm{kw}$. In the given case the best coincidence is obtained when we use the crosswind velocity at plume height.

The heat power of the plume shown in Fig. 2 was also estimated using Briggs formula (6) at distances of 1 to $4.5 \mathrm{~km}$ from the centre of the crater. The crosswind velocity was $16.6 \mathrm{~m} / \mathrm{sec}$. The height of ejections from the crater was approximately $1 \mathrm{~km}$. If the axis height of the eruption cloud is determined from crater level, then $\mathrm{Q}=236 \cdot 10^{6} \mathrm{kw}$. If we subtract the ejection height at which gases and pyroclastics rise under their own momentum, then $\mathrm{Q}=84 \cdot 10^{6} \mathrm{kw}$ (Table I).

Now we shall test the applicability of the Morton et al. formula (2) calculated for convective plume rise in calm weather conditions and a stable standard atmosphere.

The author took a photograph of the eruption column on 25 July, 1975, from Kozyrevsk, located at a distance of $47 \mathrm{~km}$ (Fig.4). The weather was calm. The top of the cloud a wide "pinia" formed at a height of $8-9 \mathrm{~km}$ above the crater of cone I of the Northern Breakthrough. According to formula (2), the plume power was $1450 \cdot 10^{6} \mathrm{kw}$ when $\Delta \mathrm{h}=9 \mathrm{~km}$ and it was $905 \cdot 10^{6} \mathrm{kw}$ when $\Delta \mathrm{h}=8 \mathrm{~km}$.

In other photographs taken in a slow crosswind in July, 1975, one may 


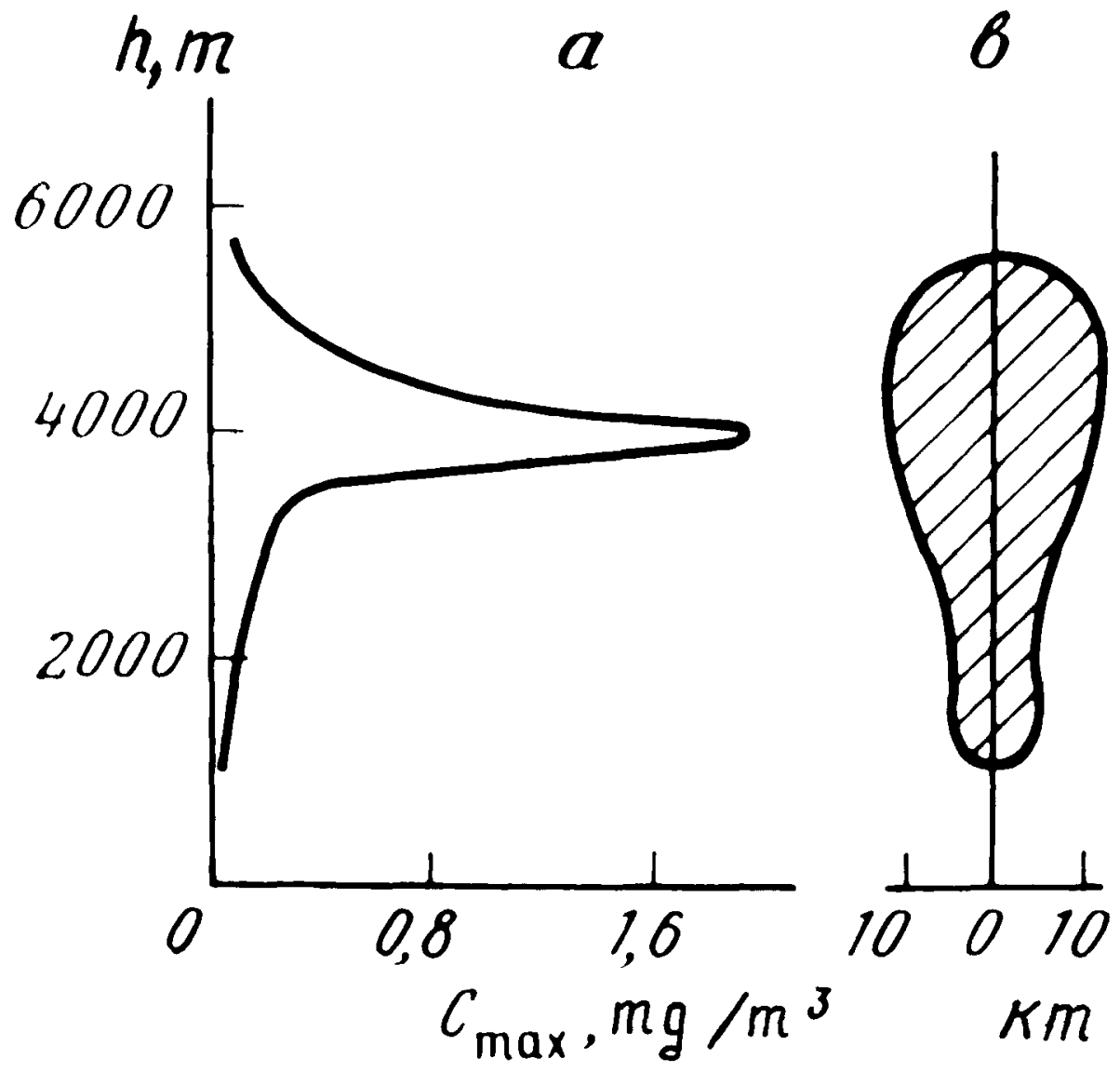

Fig. 3. Section of the plume of the Tolbachik Northern Breakthrough on 4 September, 1975 at a distance of $100 \mathrm{~km}$ from the volcano. a. distribution of maximum $\mathrm{SO}_{2}$ concentrations by height; b. geometry of cross section of the plume.

see that a curling cloud rose to a height of $7 \mathrm{~km}$ above the crater of cone I and then turned into a tail stretching down-wind. According to formula (2) $\mathrm{Q}=530 \cdot 10^{6} \mathrm{kw}$.

During the first three days (6-9 July, 1975), when the eruption became stronger, the height of the eruption column was about $5 \mathrm{~km}$. At the end of July, 1975, when most powerful activity of cone I was observed, the eruption cloud reached a height of $12 \mathrm{~km}$ and more and in August, during the cone II eruption, its height was $8-10 \mathrm{~km}$ (Fedotov et al., 1977). When $\Delta \mathrm{h}=8-12 \mathrm{~km}$ the heat power $\mathrm{Q}=(905-4630) \cdot 10^{6} \mathrm{kw}$, that is 6-31 times the expected $147 \cdot 10^{6} \mathrm{kw}$. Later on, $\Delta \mathrm{h}=7-9 \mathrm{~km}$ determined from photographs will be taken as the base values.

Unexpected discrepancy may be caused by different reasons. 
TABLE I

Estimates of heat power, Q, of gas-ash plumes and clouds of the Tolbachik and Alaid eruptions based on their height.

\begin{tabular}{|c|c|c|c|c|c|}
\hline & $\begin{array}{c}\text { Known plume heat } \\
\text { power, } \\
10^{6} \mathrm{~kW}\end{array}$ & $\begin{array}{l}\text { CONCAWE, } \\
(10)\end{array}$ & $\begin{array}{l}\text { Briggs, } \\
\text { (6) }\end{array}$ & $\begin{array}{l}\text { Morton et al, } \\
\text { M(2) }\end{array}$ & $\begin{array}{c}\text { Present } \\
\text { paper (12) }\end{array}$ \\
\hline Northern & 147 & 166 & $84-236$ & $900-1450$ & $370-560$ \\
\hline Breakthrough & & & & 530 & 230 \\
\hline Southern & $2.1-5.3$ & $2.2-5.5$ & $0.98-1.16$ & 2.35 & 2.0 \\
\hline Breakthrough & & 3.7 & & 10.2 & 7.25 \\
\hline & & & & $2.6-26.5$ & $2.2-16.7$ \\
\hline & & & & 7.4 & 5.5 \\
\hline $\begin{array}{l}\text { Alaid eruption } \\
\text { Stage I }\end{array}$ & 415 & 245 & 78.5 & & \\
\hline
\end{tabular}

Note: heat power values, $\mathrm{Q}$, are given in units of $10^{6} \mathrm{~kW}$.

Occasionally, the eruption power increased and for a few hours the amount of pyroclasts might increase by several times. In the lower $1-1.5 \mathrm{~km}$ eruption column, the plume rose under its own momentum and its free convective rise started above; therefore, the height of free rise was correspondingly less. Taking these data into consideration and assuming $\Delta \mathrm{h}=7 \mathrm{~km}$, the heat power estimate desreases to $530 \cdot 10^{6} \mathrm{kw}$. Moreover, on those days when the

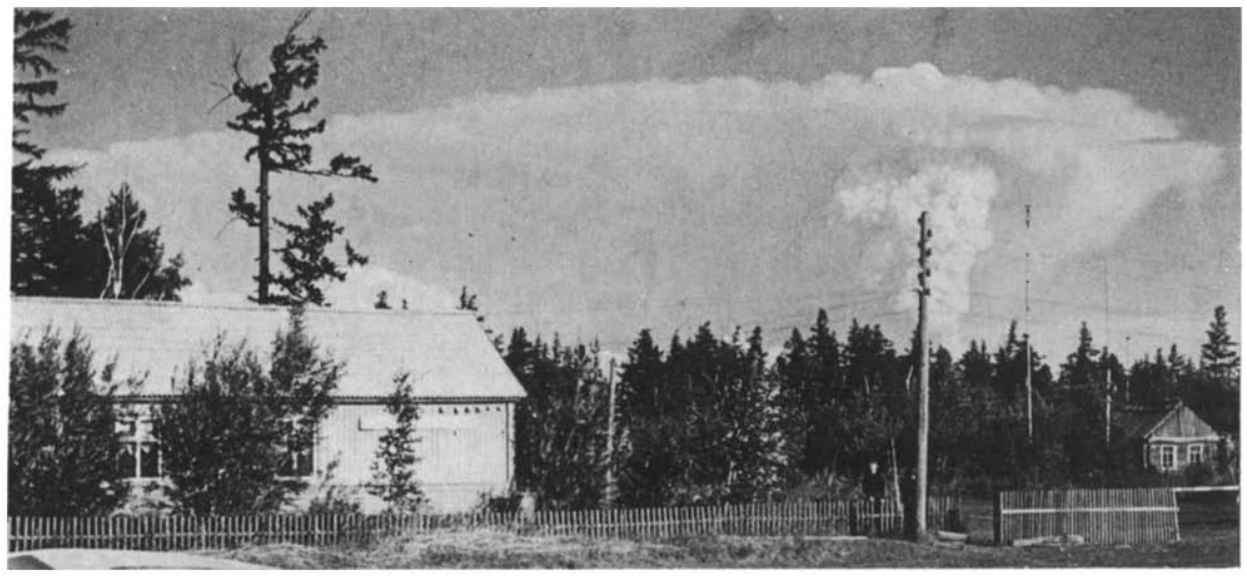

Fig. 4. Eruption cloud $8-9 \mathrm{~km}$ high above cone I of the Tolbachik eruption on 25 July 1975. Calm weather conditions. Distance is $47 \mathrm{~km}$. Photo by $\mathrm{S}$. A. Fedotov. 
top of the eruption cloud rose to 9-12 km height and more, the atmosphere might differ from the standard which was assumed in equation (2) and conditions might exist which favoured the development of ascending flows.

However, despite the above stipulations, it is clear that heat-power values obtained for the Northern Breakthrough using formula (2) are too large. The value of $Q=147 \cdot 10^{6} \mathrm{kw}$ is derived from formula (2) if $\mathrm{h}=5.08 \mathrm{~km}$. This height is too small for the top of the cloud at the Northern Breakthrough in calm weather. But it was just this very value, $\Delta \mathrm{h}$, that was observed during the first three days when the eruption was comparatively slight and during the aerial observations on 4 September, 1975, when the plume height was decreased strongly by a wind with a velocity of $26 \mathrm{~m} / \mathrm{sec}$. Thus, formula (2) overestimates the heat power of the eruption column of the Northern Breakthrough by half an order of magnitude or more.

\section{The Southern Breakthrough of the Tolbachik Eruption}

On 18 September 1975, three days after the cessation of the Northern Breakthrough activity, and at a distance of $10 \mathrm{~km}$ from it, a new fissure opened and the southern Breakthrough of the large Tolbachik fissure eruption formed (Fedotov et al., 1978; Fedotov et al., 1980). The eruption lasted there for 450 days until 10 December 1976. Its character differed strongly from that of the Northern Breakthrough. This eruption was weaker (magma discharge was only $25 \mathrm{t} / \mathrm{sec}$ compared to $265 \mathrm{t} / \mathrm{sec}$ at the Northern Breakthrough) and became effusive. The part of the volume of loose pyroclastic products at the Southern Breakthrough, E, constituted 5-6\%, while at the Northern Breakthrough E accounted for $80 \%$. Flows of fluid subalkaline basalts with temperatures of $1050-1070^{\circ} \mathrm{C}$ formed a lava sheet $35.9 \mathrm{~km}^{2}$ in area and $0.97 \mathrm{~km}^{3}$ in volume. A cinder cone which was formed on a fissure demonstrated moderate explosive Strombolian activity. Explosions occurred every 5-15 min. The pyroclastic ejection height was predominantly $150-200 \mathrm{~m}$, and at times bombs reached heights of $400 \mathrm{~m}$. The cone had grown up to $160 \mathrm{~m}$. Its volume was very small in comparison with that of the lavas and amounted to only $0.012 \mathrm{~km}^{3}$ (Gusev et al., 1979). In addition, approximately $0.022 \mathrm{~km}^{3}$ of cone material was dragged away by lava flows (Fedotov et al., 1983). The volume of pyroclastics deposited outside the cone was $0.024 \mathrm{~km}^{3}$. It was almost wholly represented by basaltic juvenile glassy ashes with particles of less than $2 \mathrm{~mm}$ in size (Budnikov et al., 1979). The total volume of fine pyroclastics reached $0.05 \mathrm{~km}^{3}$.

Water was the main constituent in magmatic gases (Markhinin et al., 1983; Menyailov et al., 1983). The water content in the magma of the Northern Breakthrough was determined approximately from the exit 
velocities of the gas-pyroclastic jet and it proved to be equal to $1.5-3 \%$. Other estimates were based on the $\mathrm{SO}_{2}$ content in the eruption plume which was measured during an aerial survey on 2, 4 and 5 September, 1975 (Abramovsky et al., 1979). These estimates have demonstrated that the gas content might attain on the average $5 \%$ by weight, accounting for $9 \%$ at the Northern Breakthrough and $0.7 \%$ at the Southern Breakthrough (Miklishansky et al,, 1979; Menyailov et al., 1980; The Great Tolbachik Fissure Eruption, 1984, ch. VII). The value of $9 \%$ is close to the limit of water solubility in basalts at great depths and seems to be too large. The data available evidence that the basaltic magma of the Southern Breakthrough might contain from 0.7 to $2 \%$ by weight of water.

Magmatic gases were released in the crater of the cone and from the surface of lava flows. It is difficult to determine the exact ratio of the quantities of these gases. Assume as a rough estimate that $2 / 3$ of magmatic gases in the gas-pyroclastic plume were emitted through the crater of the Southern Breakthrough.

The eruption proceeded rather monotonously during 450 days.

The density of lava and pyroclasts was 2.2 and $1.1 \mathrm{~g} / \mathrm{cm}^{3}$, respectively. Assume that half the hidden heat of melting was $50 \mathrm{cal} / \mathrm{g}$ of glassy basaltic pyroclastics and its heat capacity was $25 \mathrm{cal} / \mathrm{g}$. Fine-sized pyroclast discharge was equal, on the average, to $0.68-1.4 \mathrm{t} / \mathrm{sec}$. The corresponding heat power was $(0.88-1.83) \cdot 10^{6} \mathrm{kw}$.

The enthalpy of steam with a temperature of $1000^{\circ}$ was equal to $1107 \mathrm{cal} / \mathrm{g}$ (Vukalovich, 1965). Its production rate was $260-740 \mathrm{~kg} / \mathrm{sec}$ and the heat power was $1.23-3.50 \cdot 10^{6} \mathrm{kw}$.

The total heat power of the gas-pyroclastic plume of the cone at the Southern Breakthrough must have exceeded $10^{6} \mathrm{kw}$, averaging, probably, $(2.1-5.3) \cdot 10^{6} \mathrm{kw}$. This is approximately 40 times less compared to the power of the eruption column at the Northern Breakthrough.

Now we shall analyse estimates according to these formulae. On 29 August, 1976 the cone showed typical Strombolian activity: small ash explosions followed each other at intervals of a few seconds; their puffs formed a tail at a distance of $0.5 \mathrm{~km}$ from the crater (Fig. 5). The author made a film of the development of these puffs and their confluence into an eruption plume. Based on this film, the axis line of plume and crosswind velocity have been determined. The latter was calculated, based on the displacement of puff centres, and proved to be $9.9 \pm 1.3 \mathrm{~m} / \mathrm{sec}$, where 1.3 is the mean square deviation. After substituting $\Delta \mathrm{h}, \mathrm{x}$ and $\mathrm{u}$ into the Briggs formula (6) the plume heat power $\mathrm{Q}=(0.98-1.16) \cdot 10^{6} \mathrm{kw}$. This value corresponds to the average production rate of only fine-sized pyroclasts.

It is necessary to note that formula (6) is very sensitive to changes of height and velocity, the power index of which is 3 in the formula. 


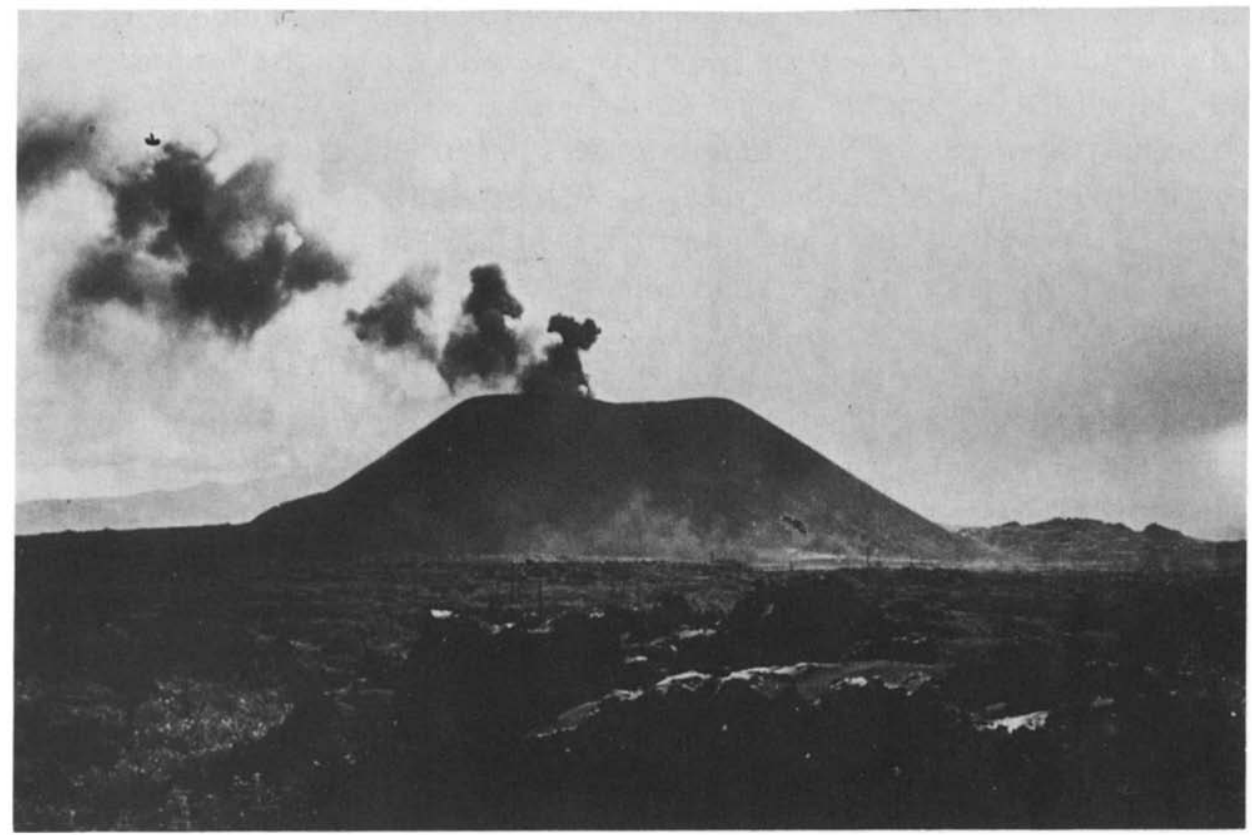

Fig. 5. Activity of the cone at the Southern Breakthrough on 29 August, 1976. The cone height above lava flows near its foot is $120 \mathrm{~m}$. Photo by S. A. Fedotov.

Let us test the applicability of the CONCAWE formula (10) using another series of observations.

In the second half of a day on 4 November, 1976, the author photographed a panorama of the plume, its formation and changes caused by pauses in the crater activity during several hours (Fig. 6). The point found for the survey was very convenient; it was at a distance of $6.7 \mathrm{~km}$ from the crater, the elevation was $600 \mathrm{~m}$, the wind was lateral, the weather was calm, and the wind velocity was about $5 \mathrm{~m} / \mathrm{sec}$. Fourteen determinations of the height of the axis line $\Delta \mathrm{h}$ for the horizontal part of the plume were made. Minimum, mean and maximum values proved to be equal to $1200,1560 \pm 150$ and $1900 \mathrm{~m}$, respectively. The plume heat powers, according to formula (10), correspondingly equal $2.2 \cdot 10^{6}, 3.7 \cdot 10^{6}$ and $5.5 \cdot 10^{6} \mathrm{kw}$. The calculated values of $\mathrm{Q}$ are in good agreement with the expected average power $(2.1-5.3) \cdot 10^{6} \mathrm{kw}$.

We shall now consider some examples of estimates in a slow crosswind. The day on 27 December 1976 was calm and fine. The eruption plume ascended as a column, expanding upwards at the end of which a white cloud could be seen. From a distance of $9 \mathrm{~km}$ from the crater, the eruption column was seen up to its top and it was photographed by Dr. Sugrobov 


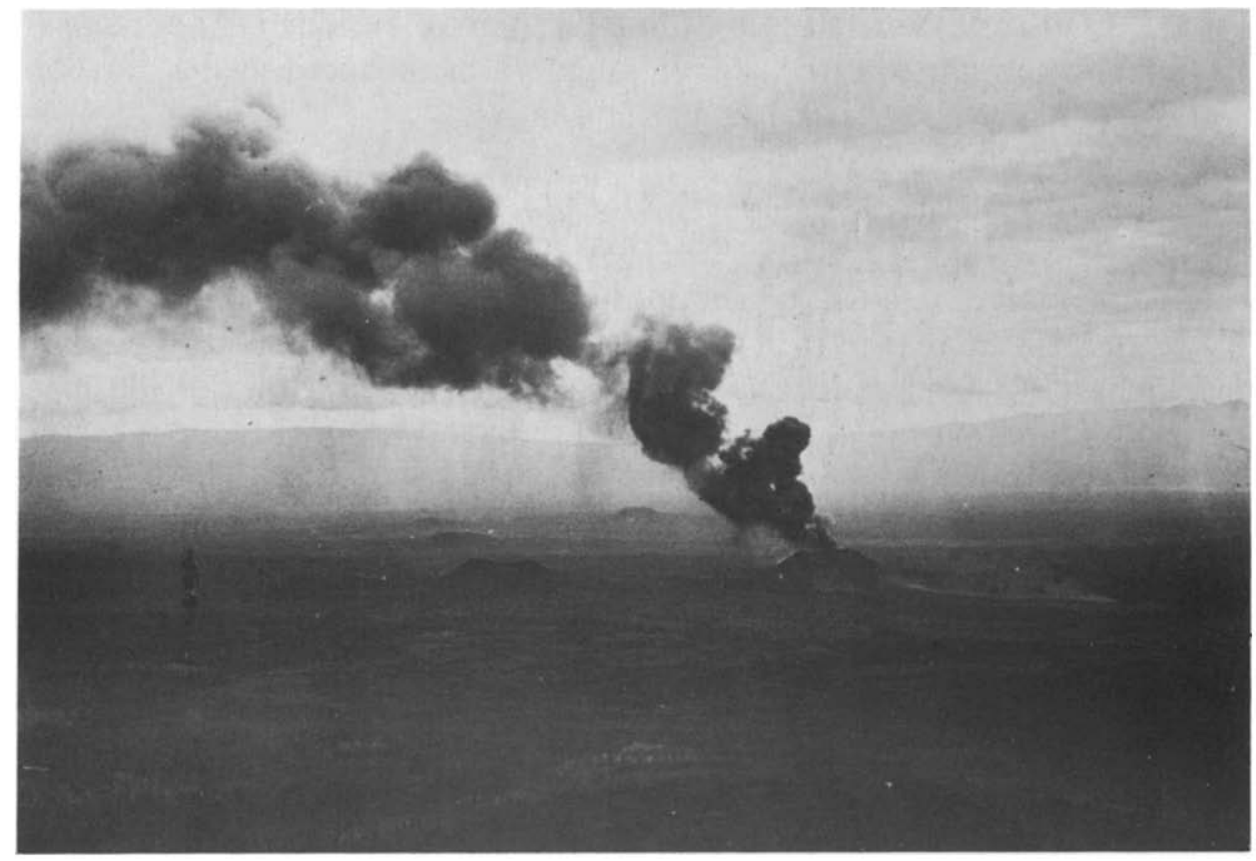

Fig. 6. Plume from the cone of the Tolbachik Southern Breakthrough in the evening on 4 September, 1976. Median line of the plume stretches horizontally $1500 \mathrm{~m}$ above the crater. Distance is $6.7 \mathrm{~km}$. Photo by S. A. Fedotov.

and by the author. On 11 July, 1976, Dr. Maguskin and the author had a similar opportunity to take a picture of the cone from a distance of $6 \mathrm{~km}$. In the first case, the top of the eruption cloud was at a height of $1800 \mathrm{~m}$, and in the second case it was at a height of $2600 \mathrm{~m}$ Substituting these values into the Morton et al. formula (2), we obtain heat power $\mathrm{Q}=2.35 \cdot 10^{6} \mathrm{~kW}$ and $10.2 \cdot 10^{6} \mathrm{kw}$. The first value corresponds that expected, the second is two to three times greater.

In the evening of 2 September, 1976 the author photographed a vertical eruption column from a distance of $10,3 \mathrm{~km}$. Unfortunately, the top of the column formed a cloudy layer and it was difficult to determine its exact height. The top of the vertically ascending plume part was higher than $1850 \mathrm{~m}$ above the crater; most likely, it was at a height of $2400 \mathrm{~m}$. The top of the cloud, displaced down the wind by $2.5 \mathrm{~km}$, was at a height of $3300 \mathrm{~m}$. According to formula (2) the heat power is respectively $2.6 \cdot 10^{6}, 7.4 \cdot 10^{6}$ and $26.5 \cdot 10^{6} \mathrm{kw}$.

Calculations made by using different formulae and the known heat power values of gas-pyroclastic plumes of the Tolbachik eruption are given in 
Table I. Q values estimated using the more precise formula (12) are shown in the extreme right column. This formula will be deduced in the next section of the paper.

\section{The Eruption of Alaid Volcano in 1981}

Alaid is a large basaltic volcano located on the Atlasov Island in the Sea of Okhotsk in the rear part of the Kurile Island arc. It is the northernmost and highest $(2340 \mathrm{~m})$ volcano of the Kurile Islands and one of the most active volcanoes of the Kurile-Kamchatka belt. It appeared about 60,000 years ago. Its average magma production rate is $8 \cdot 10^{6} \mathrm{t} / \mathrm{yr}$. The following two types of eruptions are characteristic of Alaid volcano: strong summit eruptions-during the last centuries they were only explosive; and lateral eruptions during which cinder cones appear and lava pours out along the radial fissures in the lower part of the volcano edifice (Fedotov et al., 1981; 1982).

The most recent eruption of Alaid volcano occurred from April till June 1981. This was a strong explosive eruption of the summit crater. After the 1975-1976 Tolbachik eruption, this was the largest eruption of the KurileKamchatka volcanic belt. The Alaid eruption commenced on 27 April, 1981. Its main activity, lasting 39 days, consisted of three paroxysmal phases. The eruption cloud height attained $6 \mathrm{~km}$ above the crater and the eruption cloud plume, impressive views of which were obtained from satellite photographs, extended for a distance of about $3000 \mathrm{~km}$. Approximately $0.55 \mathrm{~km}^{3}$ of pyroclasts, including $0.3 \mathrm{~km}^{3}$ of juvenile material, was erupted. In composition the eruption products were subalkaline high-alumina basalts.

Systematic observations of the eruption plume were carried out in order to estimate its heat power and the production rate of juvenile pyroclasts, using formula (10). On 28 April, 1981, during the first phase of eruption, the wind blew in the direction of Kamchatka, therefore the total amount of pyroclasts and the ratio of resurgent to juvenile material were rather precisely determined from ground-sampling data. That day $36 \cdot 10^{6} \mathrm{t}$ of juvenile basaltic ash and lapilli was ejected. Such a discharge of juvenile pyroclasts might yield a heat power of the eruption plume of approximately $415 \cdot 10^{6} \mathrm{kw}$. Using formula (10) it was found that on 29 April, 1981, the eruption plume heat power Q was equal to $245 \cdot 10^{6} \mathrm{kw}$; the height of the horizontal part of the plume, at a distance of $30 \mathrm{~km}$ from the volcano, was $\Delta \mathrm{h}=3800 \mathrm{~m}$; and the crosswind velocity $\mathrm{u}$ at the same height was $25 \mathrm{~m} / \mathrm{sec}$. More detailed data are given in the paper by Fedotov et al., (1982).

$Q$ values were also estimated using the Briggs formula (6). Increase in plume height was determined at the plume exit, where the rise of the plume was distinctly seen on 29 April, 1981. Measurements were made at distances 
of $2-8 \mathrm{~km}$ from the crater; the crosswind velocity was $25 \mathrm{~m} / \mathrm{sec}$. ${ }^{*}$ The $\mathrm{Q}$ value was estimated to be $78.5 \cdot 10^{6} \mathrm{kw}$ (Table I).

On the whole, experience in using the formulae for estimation of the heat power and production rate of juvenile pyroclasts, based upon the height of eruption plumes and clouds, proved to be successful in the case of the Tolbachik and the Alaid volcanic eruptions. A discussion of results is given in the next section.

\section{ACCURACY OF FORMULAE; NOMOGRAM AND SCALE}

In the previous section we have used the most suitable formulae from section I: (10), (6) and (2). Now we shall consider the question of their accuracy and the limits of their applicability.

The height of the eruption plume or cloud, $\Delta \mathrm{h}$, and the wind velocity, $\mathrm{u}$, have different power indices in formulae (10), (6) and (2): the lowest are in (10) and the highest are in (2). Therefore errors in determination of plume height and wind velocity must influence the estimates calculated using formulae (6) and (2) much more strongly. Other conditions being equal, it is preferable to use formula (10). Practice has confirmed this.

The best results in estimation of plume heat power, based on the height of the axis of its horizontal part in a crosswind, were obtained using the CONCAWE formula (10). Coincidence of the well-known and calculated heat power of gas-pyroclastic plumes of the Tolbachik eruption implies that formula (10) may be extrapolated from the heat power of mayor industrial stacks $\left(\mathrm{Q}=(10-100) \cdot 10^{3} \mathrm{kw}\right)$ and fumaroles to the heat power of plumes of large eruptions $\left(\mathrm{Q}=(100-300) \cdot 10^{6} \mathrm{kw}\right.$ and more $)$. The uncertainty of single estimates does not exceed 3-times. The accuracy may increase if we carry out series of observations.

The Briggs formula (6) derived for estimation of heat power, based on ascending plumes, may be used within the range of $Q=\left(10^{3}-10^{7}\right) \mathrm{kw}$, i.e., from fumaroles to strombolian eruptions. Its uncertainties are greater being, probably, close to those common for the formulae of type (1-10), i.e., errors of half an order of magnitude and more may be possible.

The known formula by Morton et al. (2), which has proved itself to be good in estimating the heights of large and small industrial smoke emissions in a stable atmosphere in slow crosswinds, yielded values overestimated by half an order of magnitude for the Southern Breakthrough and

\footnotetext{
* At large distances from the crater the eruption plume rises very slowly or remains at a ceiling height. If one uses the Briggs formula (6), Q values in this case are much underestimated, e.g. only $10 \times 10^{6} \mathrm{kw}$ for the first stage of the Alaid eruption.
} 
approximately by an order of magnitude for the Northern Breakthrough of the Tolbachik eruption (Table I). In order to elucidate the reasons for this disagreement and the limits of applicability of the formula, we shall employ the data on other large eruptions for which the production rate of pyroclasts and the maximum height of clouds are known (Table II).

Table II includes only pyroclastic material which fell out from eruption clouds; the material of pyroclastic flows was eliminated. Ejected incandescent pyroclasts were assumed to contain approximately half a hidden heat of melting and their heat capacity was taken to be $300 \mathrm{cal} / \mathrm{g}$.

Empirical data on the dependence between $\mathrm{Q}, \Delta \mathrm{h}_{\mathrm{T}}, \Delta \mathrm{h}$ and $\mathrm{u}$ are compared with theoretical relations (2) and (10) in Fig. 7.

Relation (2) was plotted for a large interval of powers $\mathrm{Q}=1-10^{13} \mathrm{kw}$ and heights from $45 \mathrm{~m}$ to $55 \mathrm{~km}$, i.e. almost to the top of the stratosphere. Its extrapolation has no sense inasmuch as $55 \mathrm{~km}$ is the theoretical limit of $\Delta \mathrm{h}_{\mathrm{T}}$ for steady convective columns of eruptions in a standard atmosphere (Wilson et al., 1978)*. Comparison of relation (2) with the actual data on eruption (Fig. 7), demonstrates a strikingly common character of the physical regularities controlling the free ascent of convective columns in the atmosphere. In the first approximation, the dependence remains true for the whole very wide $Q$ interval and for the different atmosphere layers, such as the troposphere and stratosphere, although this dependence was calculated for a steady standard atmosphere. Deviations do not exceed an order of magnitude and have regular tendencies such as real heights being higher than those calculated; deviation increasing with height in the troposphere at heights of $1-10 \mathrm{~km}$ and decreasing with height in the stratosphere at heights of $10-55 \mathrm{~km}$. According to empirical data (Fig.7) the following system of equations may fit better (Fedotov, 1981; Fedotov, 1982):

$\mathrm{Q}, \mathrm{kW}=\left(\frac{\Delta \mathrm{h}_{\mathrm{T}}, \mathrm{m}}{46}\right)^{4}, \Delta \mathrm{h}_{\mathrm{T}}<1 \mathrm{~km}$

$\mathrm{Q}, \mathrm{kW}=\left(\frac{\Delta \mathrm{h}_{\mathrm{T}}, \mathrm{m}}{28.5}\right)^{3.5}, \Delta \mathrm{h}_{\mathrm{T}}=1-10 \mathrm{~km}$

$\mathrm{Q}, \mathrm{kW}=\left(\frac{\Delta \mathrm{h}_{\mathrm{T}}, \mathrm{m}}{100}\right)^{4.5}, \Delta \mathrm{h}_{\mathrm{T}}=10-55 \mathrm{~km}$

\footnotetext{
* It is not excluded that the cloud rises higher if the conditionsin the atmosphere differ from standard. For example, it was reported that the eruption cloud of the Krakatoa volcano on 27 August, 1883 attained a height of $70-80 \mathrm{~km}$ (e.g., Gushchenko, 1979). Heights of from $47 \mathrm{~km}$ to $100 \mathrm{~km}$ and more were reported by different authors.
} 


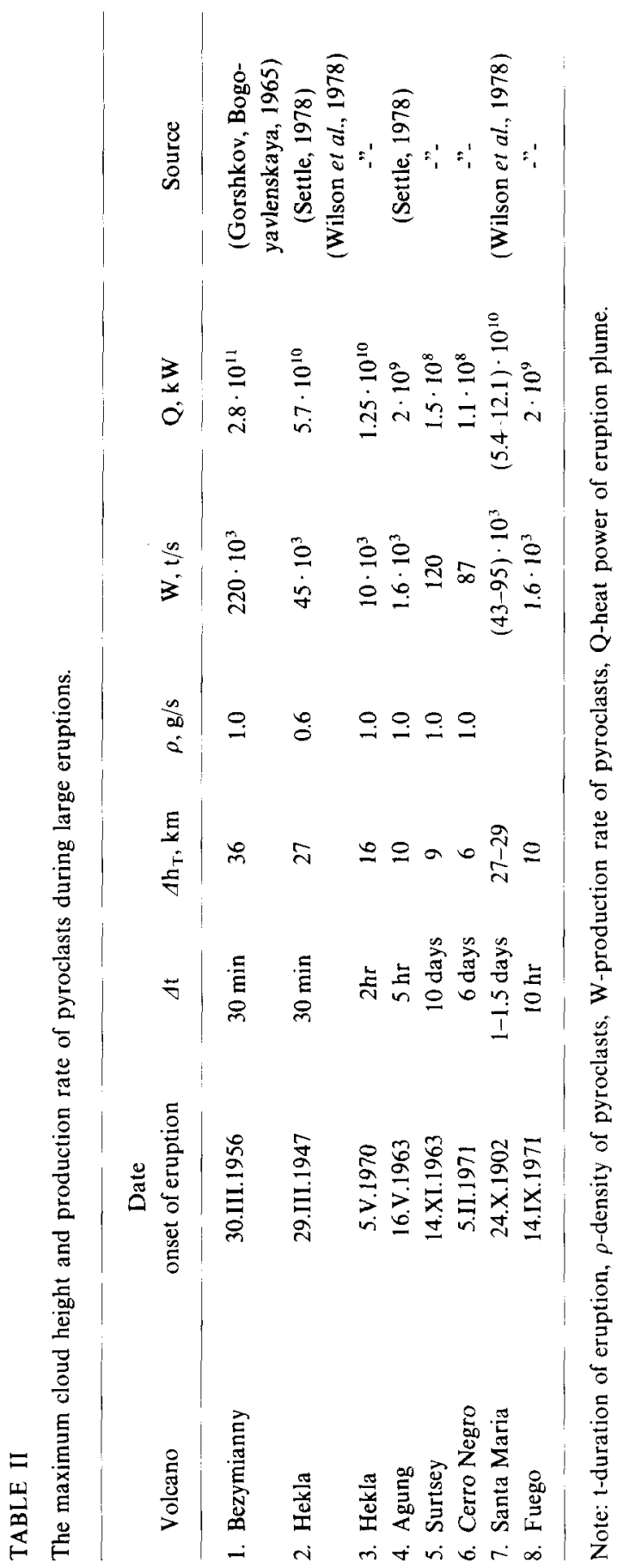




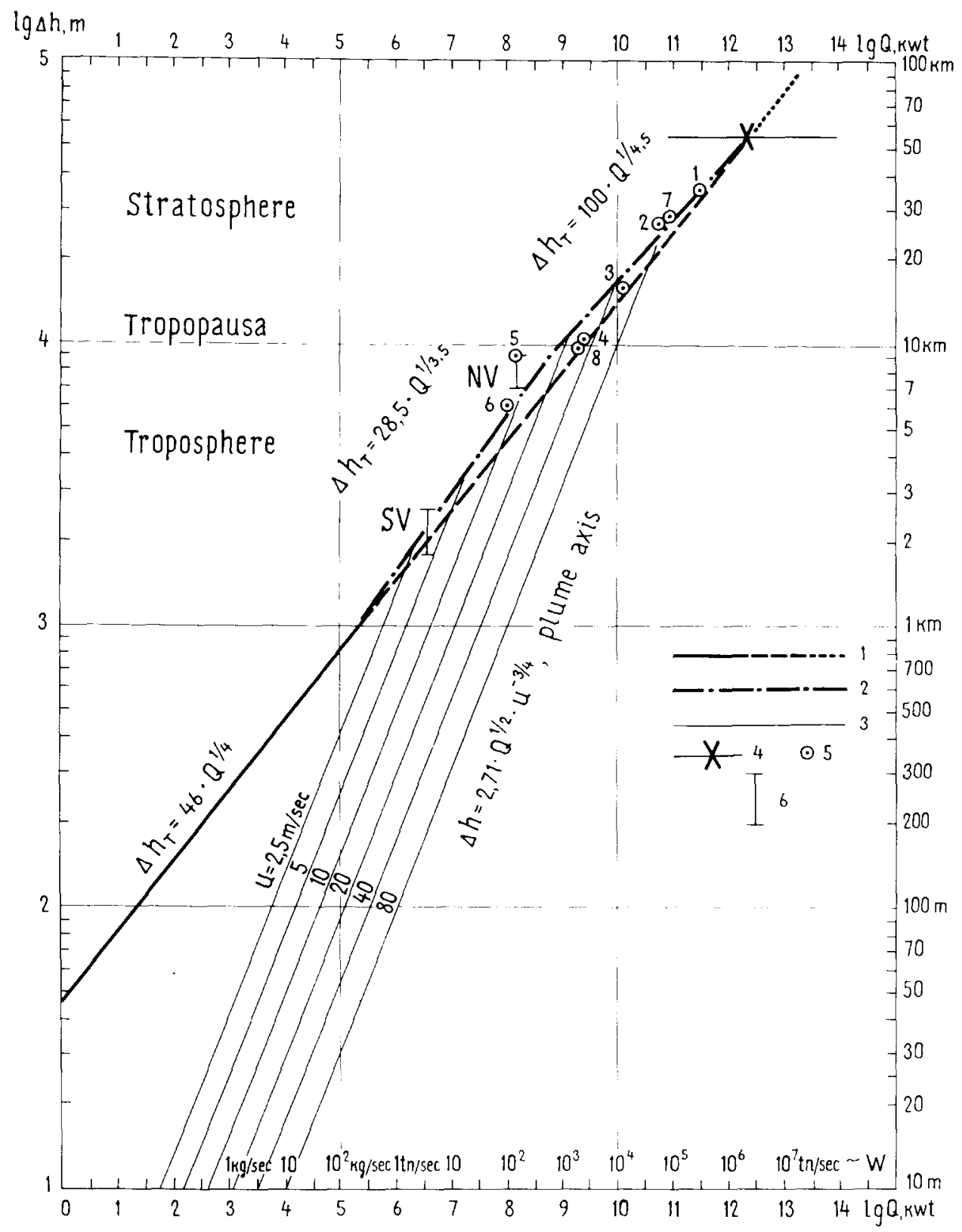

Fig. 7. Empirical and theoretical dependence of steady convective plume $\Delta \mathrm{h}$ and cloud $\Delta \mathrm{h}_{\mathrm{T}}$ height on heat power, Q, of their source. 1. plot of the Morton et al. relation (2) for a standard atmosphere in calm weather; solid line-the interval within which the calculated heights of smoke from big stacks agree well with the observed ones; broken line-the extrapolation of relation (2) to the field of eruption powers; dotted line-extrapolation of relation (2) outside the maximum $\Delta \mathrm{h}_{\mathrm{T}}$ which is possible for Plinian type volcanic eruptions. 2. relations suggested in the present paper for calculations when $\Delta \mathrm{h}_{\mathrm{T}}=1-10 \mathrm{~km}$ and 10-55 km;3. plot of the CONCAWE formula (10) for calculations with a crosswind with velocity $\mathrm{u}$; 4. the limit of Plinian eruption column height according to Wilson et al. (1978); 5. actual data on $\Delta \mathrm{h}_{\mathrm{T}}$ and $\mathrm{Q}$ for strong eruptions, Table II; $6 . \Delta \mathrm{h}_{\mathrm{T}}$ for the Norhtern and Southern Breakthroughs of the Tolbachik eruption. W-the approximate emission rate of juvenile pyroclasts per second, corresponding to $\mathrm{Q} . \Delta \mathrm{h}_{\mathrm{T}}$-the height of the top of the eruption cloud above the crater, h-the height of the median line of the horizontal part of the plume above the crater (see Fig. 1). Figure 7 may be used as a nomogram for estimation of $\mathrm{Q}$ and $\mathrm{W}$, based on $\Delta \mathrm{h}_{\mathrm{T}}, \Delta \mathrm{h}$, and $\mathrm{u}$. 
Empirical values differ from relation (12) by not more than by a factor of three*.

Using relations (2) and (12), we may determine the maximum height $\Delta \mathrm{h}_{\mathrm{T}}$ which may be attained by a convective cloud in a steady atmosphere in calm weather conditions or in a slow crosswind. The wind stretches the cloud into the plume, accelerates the mixing of plume gases with ambient air and bends the plume down to the ground. Figure 7 shows the graphs of formula (10) with allowance for wind. A successful utilization of formula (10) for the estimation of $Q$ values at the Northern and Southern Breakthroughs of the Tolbachik eruption permitted us to extrapolate graphs from the field of heat powers $Q \leqslant 120 \cdot 10^{3} \mathrm{Mw}$ to the field of heat powers of volcanic eruptions. Graphs (10) are limited from the above by relations (2) and (12), above which these graphs make no sense. Graphs (10) demonstrate clearly how the wind affects the eruption or fumarolic plume.

Thus, for example, the axis of the plume of the Tolbachik Southern Breakthrough should decrease from $1600 \mathrm{~m}$, when the wind velocity is $5 \mathrm{~m} / \mathrm{sec}$, to $300-350 \mathrm{~m}$ when the wind velocity is $40 \mathrm{~m} / \mathrm{sec}$ (see Fig. 7).

It should be noted that Fig. 7 may be used as a nomogram for estimating $\mathrm{Q}$ values based on $\Delta \mathrm{h}, \Delta \mathrm{h}_{\mathrm{T}}$ and $\mathrm{u}$. In order to melt $1 \mathrm{~g}$ of the erupted rocks approximately $1 \mathrm{kw}$ is needed. In addition to $\mathrm{Q}$ values, the corresponding values of production rate of juvenile pyroclasts, W, were plotted on the horizontal axis in Fig. 7. The nomogram in Fig.7 may also serve for estimation of the discharge rate of pyroclasts in plumes of eruptions the products of which contain predominantly juvenile material. As mentioned above, formulae (10), (6), (2), (12) and the nomogram were derived for maintained plumes but not for clouds from instantaneous sources or explosions.

The nomogram in Fig. 7 gives a possibility of estimating quantitatively the heat power, not only of recent but also of old eruptions, if realistic pictures or exact descriptions of their plumes or clouds are available. Thus, the paroxysmal summit crater eruption ("final eruption") of Vesuvius occurred on 21-24 October 1822 (Gushchenko, 1979; Carta et al., 1981). Scrope, in his book $(1825,1862)$, gives a known picture of the plinian eruption column of this eruption (Fig. 8). As is seen from Fig. 8,the eruption occurred in calm weather and the height of the top of the cloud $\Delta \mathrm{h}$ attained $7 \mathrm{~km}$ above the crater. We recall that the height of Vesuvius is $1300 \mathrm{~m}$. According to (12)

\footnotetext{
* In all appearance, it would be better to subtract the height of the initial momentum plume rise from $\Delta \mathrm{h}$. According to Wilson et al. (1982), it constitutes $\sim 10 \%$ of $\Delta \mathrm{h}$. In such a case, we may introduce a correction factor 0.9 in the value $\Delta \mathrm{h}$ in relation (12). Inasmuch as $(0.9)^{4} \approx 2 / 3$, the $\mathrm{Q}$ values decrease by $1 / 3$.
} 


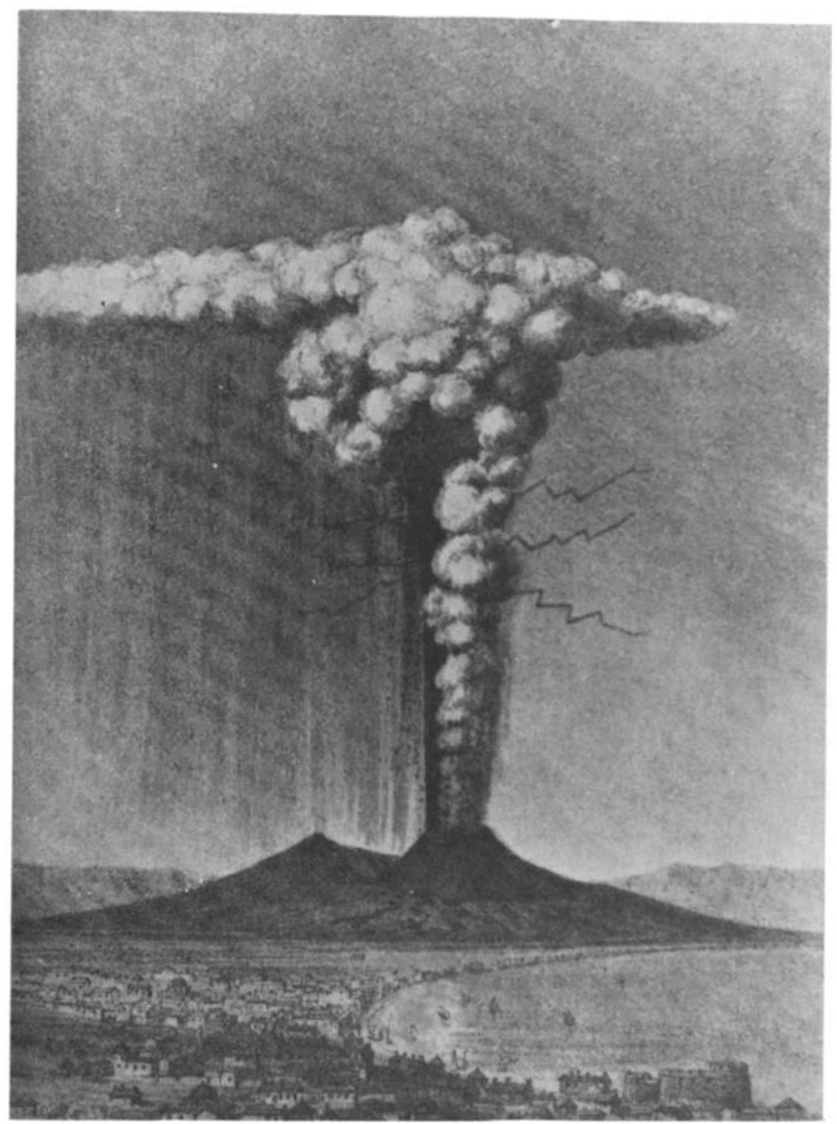

Fig. 8. Plinian column of the Vesuvius eruption in October 1822. Old picture.

and Fig. 7, the heat power of the eruption column $Q \approx 100 \cdot 10^{6} \mathrm{kw}$ and the discharge rate of juvenile pyroclasts is approximately $100 \mathrm{t} / \mathrm{sec}$. During four days of such activity, about $35 \cdot 10^{6} \mathrm{t}$ of magma or $(30-40) \cdot 10^{6} \mathrm{~m}^{3}$ of juvenile pyroclasts might have been emitted.

\section{Intensity Scale of Fumarolic and Eruptive Activity}

The history of the systematization of volcanic eruptions covers 150 years (Luchitsky, 1971). A lot of classifications of descriptive and qualitative type have been suggested. Quantitative scales of eruption intensity began to appear from 1955 (e.g., Tsuja, 1955; Hedervari, 1963). Nevertheless, the problem of quantitative classification of eruptions is not still solved. Volcanology needs valid quantitative eruption scales; it concedes in this respect to seismology (e.g., Simkin et al., 1981). 
Instrumental scales of earthquake magnitudes, expressing the quantitative measure of seismic energy radiating from their foci, have been used since 1937. More than a quarter of a century ago, scales of magnitudes and energy classes became a part of the routine of seismological investigations. However, although tectonic earthquakes differ little in mechanism compared with volcanic eruptions, a satisfactory universal scale of earthquakes could not be constructed (e.g., Fedotov, 1972). In all probability, volcanologists will have to work out a standard, generally accepted system of quantitative scales and numerical characteristics rather than a single scale in which any eruption is characterized by single figure.

A variant of a system consisting of four quantitative scales has been proposed by Walker (1980), who suggested determination of magnitude-the total volume; intensity-the emission rate; dispersive power-the extent of dispersal; violence-the importance of momentum and destructive potential.

A scale proposed by Tsuya (1955) may be used for classification of eruptions in terms of the volume of their products. The total volume of eruption products is included in it by recalculation to dense magma. Inasmuch as the errors in determining the volumes of erupted magma are usually less than an order of magnitude, the fractional magnitude values may be determined using the formula $\mathrm{VM}=\lg \left(\mathrm{V}, \mathrm{m}^{3}\right)-2$, where $\mathrm{VM}$ is the magnitude by volume and $\mathrm{V}$ is the volume.

According to Walker (1980), explosive eruptions may be of low (magma production rate is less than $1 \mathrm{~m}^{3} / \mathrm{sec}$ ), moderate (magma production rate $1-10^{3}-\mathrm{m}^{3} / \mathrm{sec}$ ), high (magma production rate $10^{3}-10^{6} \mathrm{~m}^{3} / \mathrm{sec}$ ) and very high (magma production rate $10^{6} \mathrm{~m}^{3} / \mathrm{sec}$ ) intensity. The intensity scale of eruptions may be more detailed and uniform. We suggest such a variant which is based on data from sections I and II of this paper (Table III). This scale permits us to classify the heat power of eruption and fumarolic plumes, based upon their height in calm weather. If the energy power $Q$ is estimated based on the discharge rate of pyroclasts, it is necessary to take into account the ratio of hot juvenile to cold resurgent material.

When errors in determining $Q$ are less than half an order of magnitude, the fractional intensity values are estimated using the relation $\mathrm{VI}=$ $\lg (\mathrm{Q}, \mathrm{kw})$.

The intensity scale of explosive and fumarolic activity (Table III) covers the whole range of phenomena typical of volcanic activity and may serve for their comparison and for the description of intensity changes in time. This scale becomes visual if we draw an analogy with the intensity scale of earthquakes: fumarolic activity of different intensities-I-IV; small eruptions-V; the Tolbachik Northern Breakthrough plumes-VIII; and the largest well-known eruptions-XI intensity units.

Discussion of other scales is beyond the scope of this paper. 


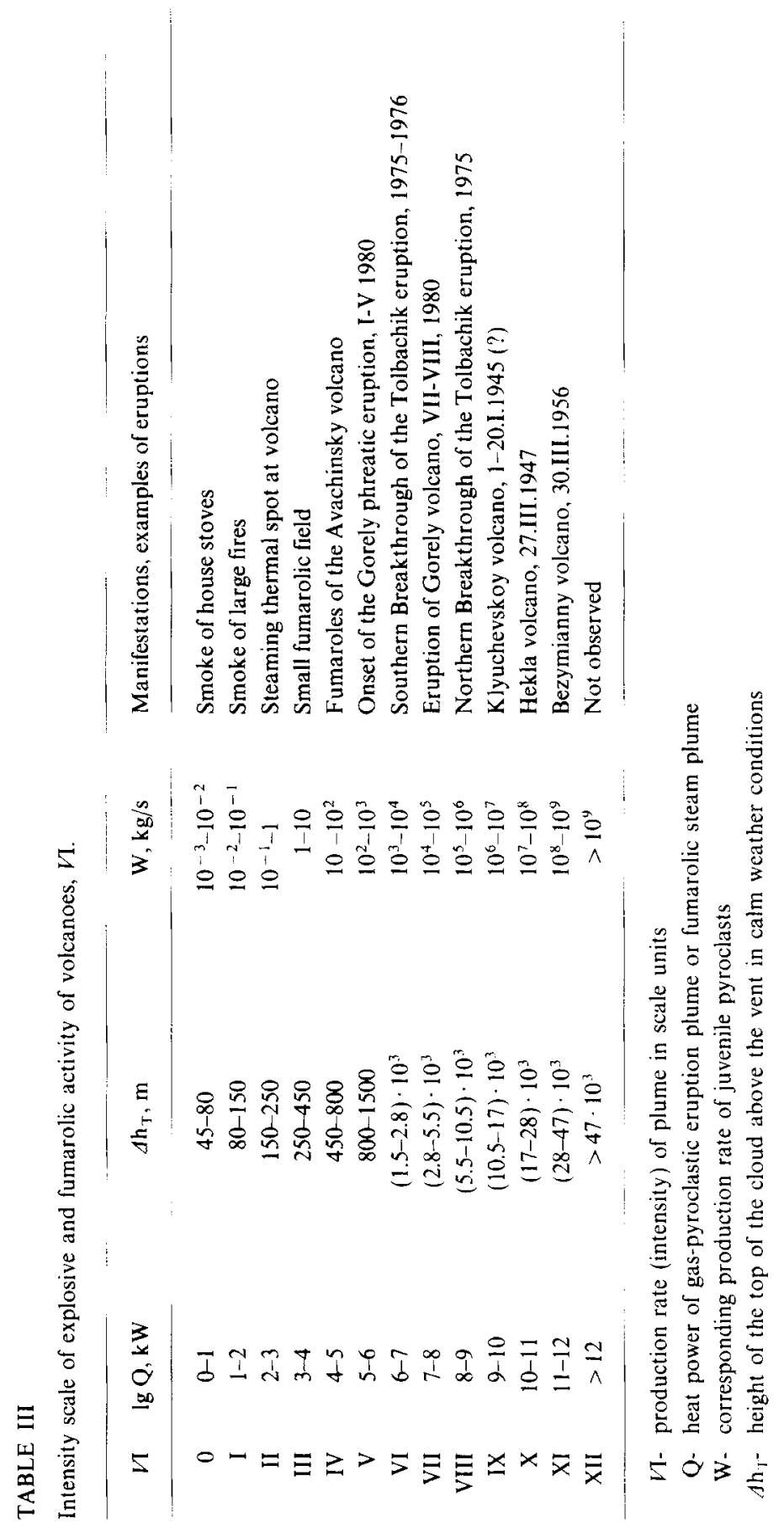




\section{CONCLUSION}

The main conclusions of this study are as follows. The well-studied eruptions of Kamchatkan volcanoes were considered. It is confirmed that the heat power of volcanic explosive eruptions and fumaroles, as well as the emission rate of juvenile pyroclasts during eruptions, may be successfully estimated based upon the height of their plumes, tails and clouds. Errors in estimates are within half an order of magnitude; they decrease significantly under good meteorological conditions and when series of measurements are carried out. This method is rapid, convenient and worthy of systematic employment during volcanological surveillance, especially during eruptions. The author shares the opinion that this method may be a necessary part of monitoring of the state of active volcanoes.

When observing the initial part of an ascending plume which has a continuous source in crosswinds, the Briggs's formula (6) may be used. The results depend only little on the state of the atmosphere. Plume height above the crater was measured at distances of up to $10 \mathrm{~km}$ from the crater.

When observations of the horizontal portion of the plume are carried out in a crosswind, it is reasonable to use the CONCAWE formula (10). This formula has good accuracy and also may be used under various meteorological conditions (Fig. 7). In deducing these estimates, the eruption plume height was measured at distances of up to $100 \mathrm{~km}$ from the crater.

In a slow crosswind in a stable atmosphere, when plumes turn into vertical columns, it is suggested to use the relations (12). They are different for eruption cloud heights of $100 \mathrm{~m}$ to $1 \mathrm{~km}, 1$ to $10 \mathrm{~km}$ and 10 to $55 \mathrm{~km}$ (Fig. 7). If the eruption is an explosion, the atmosphere is stable and the crosswind is slow, the formula proposed by Morton et al. (4) is applicable for estimation of the energy of eruption.

A number of other formulae from section I may be used when the vertical temperature gradient of the atmosphere is known.

In order to classify and compare the volcanic phenomena in terms of their energy, the intensity scale of explosive and fumarolic activity, scale VI, is suggested.

\section{ACKNOWLEDGMENTS}

The author sincerely thanks Drs. J. W. Head, L. Wilson, R. S. J. Sparks, $T$. Kagiyama and other colleagues who have sent him their publications. The author is also grateful to Dr. V. M. Sugrobov, Dr. M. A. Maguskin, V. A. Podtabachny and others for the photographs of volcanic eruptions in Kamchatka, as well as to Dr. Yu. B. Slezin and V. K. Panov for their comments. 


\section{REFERENCES}

Abramovsky, B. P., Ionov, V. A., Nazarov, I. M., Patrakeev, S. I., Fedotov, S. A. and Chirkov, V. P., 1979. Gases and aerosol products of the Tolbachik eruption, North vents, 1975, Volcanol. and Seismol., No.3, p. 3-8 (in Russian).

Briggs, G. A., 1969. Plume rise, Atomic Energy Commision, Critical Series, USEAG Rep. TID-25075, $64 \mathrm{p}$.

Briggs, G. A., 1971. Plume rise: a recent critical review, Nuclear Safety, vol. 12, No. 1, p. 15-24.

Budnikov, V. A., Malayev, E. F. and Ovsyannikov, A. A., 1979. Comparative characteristics of ashes during the large the large Tolbachik fissure eruption in 1975-1976, North and South vents, Bull. Volcanol. Stations, No. 56, p. 131-143 (in Russian).

Budnikov, V. A., Markhinin, E. K. and Ovsyannikov, A. A., 1983. The quantity, distribution and petrochemical features of pyroclastics of the Great Tolbachik Fissure Eruption, in The Great Tolbachik Fissure Eruption, geological and geophysical data, 1975-1976, edited bt S. A. Fedotov and E. K. Markhinin, Cambridge Univ. Press, p. 41-56.

Carta, S., Figari, R., Sartoris, G., Sassi, E. and Scandone, R., 1981. A statistical model for Vesuvius and its volcanological implications, Bull. Volcanol., 44: 129-152.

Fedotov, S. A., 1972. Energy classification of the Kurile-Kamchatkan earthquakes and the problem of magnitudes, Moscow, Nauka, 116 p. (in Russian).

Fedotov, S. A., 1982. Evaluation of heat and pyroclastic discharge by volcanic eruptions and fumaroles based onthe height of their plumes and clouds, Volcanol. and Seismol., No. 4, p. 3-28 (in Russian).

Fedotov, S. A., 1982a. Dependence of volcanic plume heights on thermal and pyroclastic production rate of eruptions, Tests, IAVCEI-IAGC Sci. Ass., Reykjavik, Iceland, Generation of Major Basalt Types, abstracts, p. 104.

Fedotov, S. A., Chirkov, A. M., Andreev, V. N., Gusev, N. A., Razina, A. A. and Khrenov, A. P., 1977. Brief description of the Tolbachik fissure eruption in 1975, Bull. Volcanol. Stations, No. 53, p. 3-12 (in Russian).

Fedotov, S. A., Chirkov, A. M., Gusev, N. A., Kovalev, G. N. and Slezin, Yu. B., 1980. The large fissure eruption in the region of Plosky Tolbachik volcano in Kamchatka, 1975-1976, Bull. Volcanol., 43: $47-60$.

Fedotov, S. A., Ivanov, B. V., Avdeiko, G. P., Flerov, G. B., Andreev, V. N., Doubik, Yu. M., Dvigalo, V. N. and Chirkov, A. M., 1981. The Alaid volcano eruption in 1981, Volcanol. and Seismol., No. 5, p. 82-87 (in Russian).

Fedotov, S. A., Ivanov, B. V., Flerov, G. B., Avdeiko, G. P., Budnikov, V. A., Andreev, V. N., Gordeev, E. I., Dvigalo, V. N. and Shirokov, V. A., 1982. Eruption of the Alaid volcano (Kurile Islands) in 1981, Volcanol. and Seismol., No. 6, p. 9-27 (in Russian).

Fedotov, S. A., Kovalev, G. N., Markhinin, E. K., Slezin, Yu. B., Tsiurupa, A. I., Gusev, N. A., Andreev, V. N., Leonov, V. L. and Ovsyannikov, A. A., 1983. Chronology and features of the Southern Breakthrough of the Great Tolbachik Fissure Eruption 1975-1976, in The Great Tolbachik Fissure Eruption, geological and geophysical data, 1975-1976, edited by S. A. Fedotov and E. K. Markhinin, Cambridge Univ. Press, p. 11-26.

Gorshkov, G. S. and Bogoyavlenskaya, G. E., 1965. Bezymianny volcano and the peculiarities of its recent eruption in 1956-1963, Moscow, Nauka, 171 p. (in Russian).

Gostintsev, Yu. A., Sukhanov, L. A. and Solodovnik, A. F., 1980. Limit laws of unsteady freely ascending turbulent convective motions in the atmosphere, Dokl. Akad. Nauk., vol. 252, No. 2, p. 311-314 (in Russian).

Gusev, N. A., Dvigalo, V. N., Dobrynin, N. F., Maguskin, M.A., Seleznev, B. V., Skuridin, Yu. F. and Shkred, V. I., 1979. Some results of experimental investigations on application of the photogram- 
metric method for studies of dynamic processes in volcanology, Volcanol. and Seismol., No. 3, p. 30-36 (in Russian).

Gushchenko, I. I., 1979. Eruptions of the Volcanoes of the World, Catalogue, Moscow, Nauka, $475 p$. (in Russian).

Hedervari, P., 1963. On the energy and magnitude of volcanic eruptions, Bull. Volcanol., 25: 374-385.

Kagiyama, T., 1981. Evaluation methods of heat discharge and their applications to the major active volcanoes in Japan, J. Volcanol. Geotherm. Res., 9: 87-97.

Kagiyama, T. and Hagiwara, M., 1981. Geothermal survey in and around $\mathrm{O}$-ana crater and Jodo-daira flat, the volcanoes Azuma, Bull. Earthquake Res. Inst., 56: 681-703.

Kienle, J. and Shaw, G. E., 1979. Plume dynamics, thermal energy and long-distance transport of vulcanian eruption clouds from Augustine volcano, Alaska. J. Volcanol. Geotherm. Res., 6: $139-164$.

Knox, J. B. and Short, N. M., 1964. A diagnostic model using ashfall data to determine eruption characteristic and atmospheric conditions during a major volcanic event, Bull. Volcanol., 27: 5-24.

Luchitsky, I. V., 1971. The bases of paleovolcanology, Tome I, Recent Volcanoes, Moscow, Nauka, 479 p. (in Russian).

Maleyev, E. F., Budnikov, V. A., Ovsyannikov, A. A., Shevchuk, N. D., Zazakin, D. D. and Potylitsyn, V. A., 1979. Industrial estimate of scordia of the large Tolbachik fissure eruption, North vents, Bull. Volcanol. Stations, No. 56, p. 142-148 (in Russian).

Markhinin, E. K., 1958. On the quantity of juvenile water participatingin volcanic explosions, Dokl. Akad. Nauk., vol. 119. ser. 3, p. 537-539 (in Russian).

Markhinin, E. K., 1980. Volcanoes and life (problems of biovolcanology), Moscow, Mysl, 196 p. (in Russian).

Markhinin. E. K., Urakov, V. A., Podkletnov, N. E. and Ponomarev, V. V., 1983. Gases from the basalt flows of the Tolbachik Fissure Eruption 1975-1976, in The Great Tolbachik Fissure Eruption, geological and geophysical data, 1975-1976, edited by S. A. Fedotov and E. K. Markhinin, Cambridge Univ. Press, p. 156-163.

Menyailov, I. A., Nikitina, L. P., Vergasova, L. P., Guseva, R. V., Shapar, V. N. and Rozhkov, A. M., 1983. Chemistry, metal content and reaction products of gases from New Tolbachik volcanoes of 1975, in The Great Tolbachik Fissure Eruption, geological and geophysical data, 1975--1976, edited by S. A. Fedotov and E. K. Markhinin, Cambridge Univ. Press, p. 164-175.

Menyailov, I. A., Nikitina, L. P. and Shapar, V. N., 1980. Geochemical features of exhalations of the Great Tolbachik Fissure Eruption, Moscow, Nauka, 235 p. (in Russian).

Morton, B. R., Taylor, G. and Turner, J. S., 1965. Turbulent gravitational convection from maintained and instantaneous sources, Proc. R. Soc., Ser. A, 234: 1-23.

Sawada, Y., 1983. Analysis of eruption clouds by the 1981 eruptions of Alaid and Pagan volcanoes with GMS images, Papers in Meteorology and Geophysics, 34: 307-324.

Scrope, G. P., 1862. Consideration on volcanoes, W. Phillips and G. Yord Pub., London, 1825, 270 p., Volcanoes, 2nd ed., London.

Settle, M., 1978. Volcanic eruption clouds and the thermal output of explosive eruptions, J. Volcanol. Geotherm. Res., 3: 309-324.

Simkin, T., Siebert, L., McClelland, L., Bridge, D., Newhall, C. and Latter, J. H., 1981. Volcanoes of the World, Smiths. Inst., Hutchinson Ross Publ. Co., Stroudsbourg, Pennsylvania, 233 p.

Sparks, R. S. J. and Wilson, L., 1976. A model of the formation of ignimbrite by gravitational column collapse, J. Geol. Soc. London, 132: 441-451.

Sparks, R. S. J. and Wilson, L., 1982. Explosive volcanic eruptions, V, Observations of plume dynamics during the 1979 Soufriere eruption, St. Vincent, Geophys. J. R. Astr. Soc., 69: 551-570.

The Great Tolbachik Fissure Eruption, Kamchatka, 1975-1976, edited by S. A. Fedotov, 1984, Moscow, Nauka, 637 p. (in Russian). 
Tsuya, H., 1955. Geological and petrological studies of volcano Fuji, 5, On the 1707 eruption of the volcano Fuji, Bull. Earthquake Res. Inst., Tokyo Univ., 33: 341-384.

Vukalovich, M. T. Tables of thermodynamic properties of water and water vapour, Moscow-Leningrad, Energy, 400 p. (in Russian).

Walker, G. P. L., 1980. The Taupo pumice: product of the most powerful known (ultraplinian) eruption J. Volcanol. Geotherm. Res., 8: 69-94.

Walker, G. P. L., Wilson, L. and Bowell, E. L. G., 1971. Explosive volcanic eruptions, I, The rate of fall of pyroclasts, Geophys. J. R. Astr. Soc., 22: 377-383.

Wark, K. and Warner, C. F., 1976. Air pollution, its origin and control, IEP-Dun Donneley, Harper and Row Publ., N.Y., Hagerstown, San Franc., London, (539 p. in Russian translation, Moscow, Mir, 1980).

Williams, H. and McBirney, A. R., 1979. Volcanology, Freeman, Cooper and Co., San Franc., 397 p.

Wilson, L., 1976. Explosive volcanic eruptions, III, Plinian eruption columns, Geophys. J. R. Soc.. 45: $543-556$.

Wilson, L., 1980. Relationships between pressure, volatile content and ejecta velocity in three types of volcanic explosions, J. Volcanol. Geotherm. Res., 8: 297-313.

Wilson, L. and Head, J. W., 1981. Ascent and eruption of basaltic magma on the Earth and Moon, J. Geophys. Res., 86 (B4): 2971-3001.

Wilson, L., Sparks, R. S. J., Huang, T. C. and Watkins, N. D., 1978. The control of volcanic column heights by eruption energetics and dynamics, J. Geophys. Res., 84 (B4): $1829-1836$. 